Provided for non-commercial research and education use. Not for reproduction, distribution or commercial use.

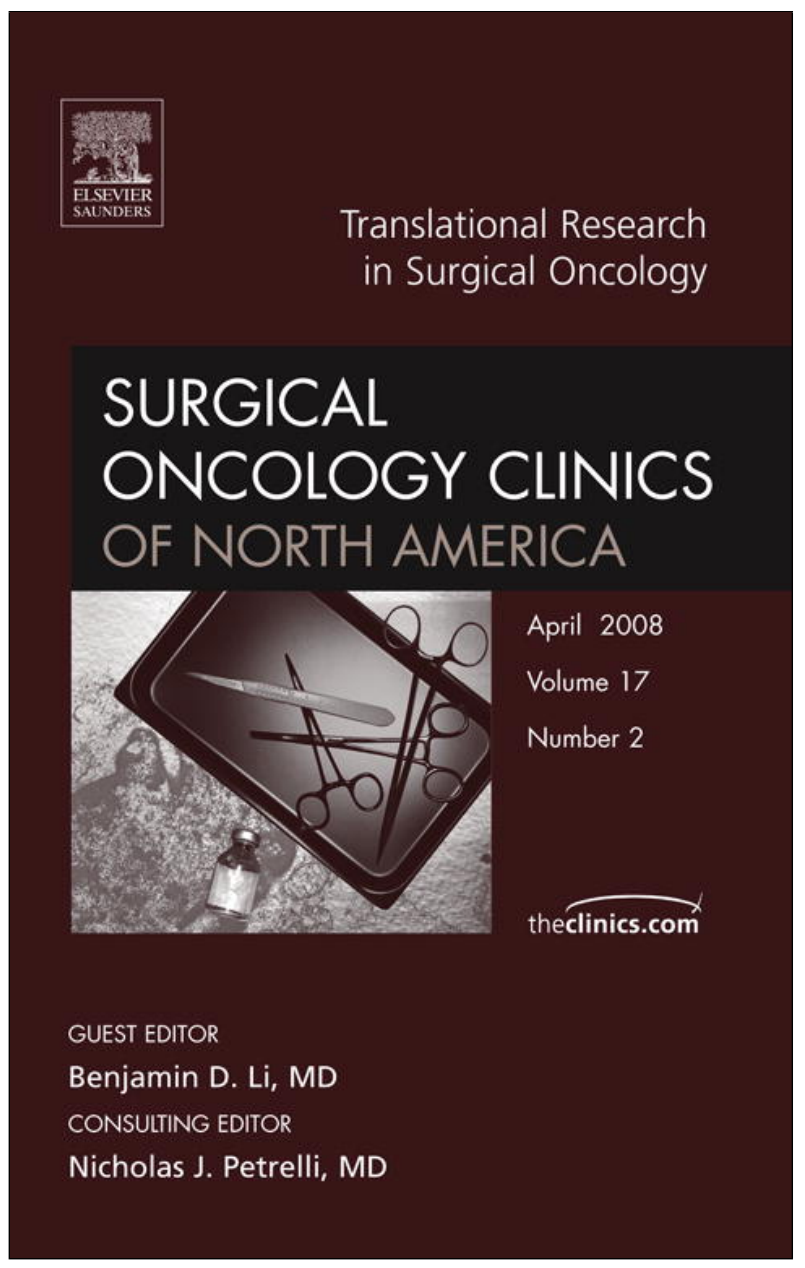

This article appeared in a journal published by Elsevier. The attached copy is furnished to the author for internal non-commercial research and education use, including for instruction at the authors institution and sharing with colleagues.

Other uses, including reproduction and distribution, or selling or licensing copies, or posting to personal, institutional or third party websites are prohibited.

In most cases authors are permitted to post their version of the article (e.g. in Word or Tex form) to their personal website or institutional repository. Authors requiring further information regarding Elsevier's archiving and manuscript policies are encouraged to visit:

http://www.elsevier.com/copyright 


\title{
Translational Research in Melanoma
}

\author{
Susan Tsai, MD, Michael S. Sabel, MD* \\ University of Michigan Comprehensive Cancer Center, University of Michigan Health System, \\ 1500 East Medical Center Drive, Ann Arbor, MI 48109, USA
}

Current treatment of malignant melanoma exemplifies not only the need for translational research but also many of the frustrating challenges of moving from the bench to the bedside. Melanoma remains somewhat unique among solid tumors in that its treatment, at early stage or advanced disease, primarily is surgical. Although adjuncts may play a role in some situations, radiation is of limited benefit and, more importantly, chemotherapy has been uniformly disappointing in adjuvant and metastatic settings. This leaves clinicians with few viable options for reducing the chance of recurrence after surgery and for treating unresectable disease. This fact is even more sobering when considering the rate at which malignant melanoma is increasing in the United States and worldwide. It is with this cost in mind that there has been a fervent attempt to identify novel approaches to melanoma therapy and rapidly translate these therapeutic approaches to clinical use.

Unfortunately, there are several obstacles to translational research in melanoma. Animal models of melanoma are limited in their translatability to the human model, particularly regarding carcinogenesis. Despite the widespread use of the murine B16 melanoma cell line in preclinical studies, it is a model for transplantable tumors, which differ inherently from spontaneously arising melanomas, limiting translatability, particularly when studying immunotherapy. Further, although there is a wealth of promising preclinical data focusing on the unique relationship between melanoma and the immune system, immunotherapy has yet to be translated to the clinical setting successfully. There even has yet to be a randomized trial demonstrating an overall survival benefit to melanoma vaccines. Areas of research that are making great strides in other solid tumors, such as tumor markers or genomic analysis, are hampered in melanoma not only by differences in

* Corresponding author. University of Michigan Health System, 3304 Cancer Geriatric Center/0932, 1500 East Medical Center Drive, Ann Arbor, MI 48109.

E-mail address: msabel@umich.edu (M.S. Sabel). 
biology but also by the limited availability of fresh primary tumor specimens for study.

Notwithstanding these challenges, recent studies have provided muchneeded insight into melanoma biology, prompting exciting areas of clinical research into the prevention and treatment of melanoma, including targeted therapies and new approaches to immunotherapy.

\section{Chemoprevention of melanoma}

Although the majority of translational research in melanoma focuses on therapy, increasing knowledge of the genetic and molecular events responsible for melanoma development has prompted a search for strategies to prevent melanoma. UV radiation likely is the primary initiating event in most melanomas, causing direct DNA damage through signature mutations $(\mathrm{C} \rightarrow$ $\mathrm{T}$ and $\mathrm{CC} \rightarrow \mathrm{TT}$ ) that have been documented in genes associated with melanocytes transformation, such as the oncogenes NRAS or BRAF or the tumor-suppressor gene CDKN2A [1-4]. Beyond malignant transformation, UV radiation also causes damage to nonmelanocytic cells (keratinocytes and dendritic cells [DCs]). This can lead to the loss of local control and suppression of the local immune response, contributing to the subsequent formation and proliferation of melanoma [1,5]. Strategies to preventing melanoma address some or all of the events related to UV radiation, including inducing apoptosis of DNA-damaged melanocytes or nonmelanocytic cells, enhancement of DNA repair, and enhancement of local immune responses [6].

The design and implementation of chemoprevention strategies face several unique challenges compared with therapeutic strategies. First, the agents of choice must have little to no toxicity; otherwise, there is poor compliance [7]. The use of a single agent may not be ideal; combinations of agents with a broad spectrum of anticarcinogenic mechanisms likely are needed given the heterogeneity of the carcinogenesis process. Finally, translating chemoprevention from bench to bedside is challenging (for reasons discussed previously). Animal models of UV-induced melanoma do not mimic human melanoma development completely, although the newly described transgenic hepatocyte growth factor/scatter factor mouse model seems most characteristic of human melanoma [8]. The ultimate goal, to demonstrate the ability of these interventions to prevent melanoma in prospective randomized trials, will be extremely costly, as it will require large populations to be studied for long periods of time. Alternatively, researchers will need to identify and validate surrogate endpoint biomarkers [9].

Despite these challenges, several agents have emerged as candidate chemoprevention agents in melanoma, some of which are summarized in Table 1. Several of these agents occur naturally. Curcumin is the major yellow pigment extracted from turmeric, a spice used commonly in India and Southeast Asia. Resveratrol is found in grapes, mulberries, and peanuts. 
Table 1

Agents proposed for chemoprevention of melanoma

\begin{tabular}{|c|c|c|c|}
\hline Agent & Mechanism & Potential & Side effects \\
\hline Statins & $\begin{array}{l}\text { Inhibition of protein prenylation, } \\
\text { preventing post-translational } \\
\text { modification of the Ras superfamily, } \\
\text { diminishing their oncogenicity }\end{array}$ & $\begin{array}{l}\text { Strong preclinical data. Epidemiologic } \\
\text { studies fail to demonstrate a significant } \\
\text { decrease in melanoma among statin users. }\end{array}$ & $\begin{array}{l}\text { Small risk for myositis but otherwise good } \\
\text { side-effect profile, including cardiovascular } \\
\text { benefit }\end{array}$ \\
\hline Curcumin & $\begin{array}{l}\text { Multiple, including antioxidant, inhibition } \\
\text { of tyrosine kinases, COX and lipoxygenase } \\
\text { inhibition, suppression of NF-кB }\end{array}$ & $\begin{array}{l}\text { Good preclinical data in B16 melanoma } \\
\text { and UV-induced carcinogenesis. Limited } \\
\text { absorption and rapid metabolism are } \\
\text { limiting factors. }\end{array}$ & $\begin{array}{l}\text { Topical: yellow staining of skin } \\
\text { Oral: excellent tolerance }\end{array}$ \\
\hline Reservatrol & $\begin{array}{l}\text { Scavenging of free radicals, suppression of } \\
\text { NF- } \mathrm{B}, \mathrm{COX} \text { inhibition }\end{array}$ & $\begin{array}{l}\text { Topical administration shows several } \\
\text { mechanisms of action in preclinical data. } \\
\text { Oral administration still being studied }\end{array}$ & Minimal \\
\hline $\begin{array}{l}\text { Epigallocatechin- } \\
\text { 3-gallate }\end{array}$ & $\begin{array}{l}\text { Protection against UV-induced COX activity } \\
\text { and prostaglandin production. Free radical } \\
\text { scavenger. Increase in IL-12 and } \\
\text { augmented immune response. }\end{array}$ & $\begin{array}{l}\text { Topical administration inhibits tumor } \\
\text { formation in mice. No strong evidence in } \\
\text { melanoma, although people have used } \\
\text { green tea for chemoprevention of other } \\
\text { cancers for many years. }\end{array}$ & Little to no side effects \\
\hline Silymarin & $\begin{array}{l}\text { Scavenging of free radicals, suppression of } \\
\text { NF-אB, COX inhibition. Inactivation of } \\
\text { PI3K-Akt and MAPK signaling. }\end{array}$ & $\begin{array}{l}\text { Most data in nonmelanoma skin cancers. } \\
\text { Limited preclinical data for melanoma. }\end{array}$ & Excellent tolerance \\
\hline Sorafenib & $\begin{array}{l}\text { Inhibition of Raf kinase and receptor } \\
\text { tyrosine kinases leading to apoptosis } \\
\text { of melanoma cells }\end{array}$ & $\begin{array}{l}\text { Promising data on treatment of melanoma. } \\
\text { Associated pathways are appealing targets } \\
\text { for chemoprevention but limited data. }\end{array}$ & $\begin{array}{l}\text { Significant for chemoprevention, including } \\
\text { rash and hypertension. }\end{array}$ \\
\hline $\begin{array}{l}\text { COX-2 } \\
\quad \text { inhibitors }\end{array}$ & $\begin{array}{l}\text { COX inhibition, prevention of UV-induced } \\
\text { prostaglandin production }\end{array}$ & $\begin{array}{l}\text { Promising mouse data. Case control studies } \\
\text { suggest a decreased incidence of melanoma } \\
\text { in patients on a COX inhibitor. }\end{array}$ & Significant cardiac risk precluding use \\
\hline Retinoids & $\begin{array}{l}\text { Induction of apoptosis by binding of } \\
\text { RAR or RXR in nuclei and interference } \\
\text { of transcription factors controlling } \\
\text { differentiation and proliferation }\end{array}$ & $\begin{array}{l}\text { Shown effective in nonmelanoma skin } \\
\text { cancers. Limited data on melanoma; } \\
\text { however, } \\
\text { because melanoma is relatively apoptosis } \\
\text { resistant, there is promise. }\end{array}$ & $\begin{array}{l}\text { Need careful monitoring for } \\
\text { hypercholesterolemia, } \\
\text { hypertriglyceridemia, increased LFTs, } \\
\text { myalgias/arthralgias, and dry skin and } \\
\text { mucous membranes. }\end{array}$ \\
\hline
\end{tabular}


Epigallocatechin-3-gallate is the major constituent of green tea. As understanding of melanocyte biology and carcinogenesis improves, more agents likely will be identified as potential instigators. A dedicated effort by basic scientists and clinicians will be necessary to move forward and potentially prevent the development of melanoma in high-risk populations.

\section{Targeted therapies in melanoma}

\section{Inhibitors of signal transduction}

Recent studies have shed light on the cumulative genetic and molecular events that result in neoplasia. Transforming mutations in oncogenes and loss of heterozygosity of tumor suppressor genes have been a major focus of target molecular therapies. Transforming mutations in oncogenes can have an impact on pathways that regulate cellular proliferation, differentiation, cell cycle control, and apoptosis. Two such pathways have garnered significant interest in the field of melanoma biology: the RAS- mitogen-activated protein kinase (MAPK) pathway and the phosphoinositide kinase-3 (PI3K)/AkT pathway.

The MAPK signal transduction pathway has been of significant interest since the discovery of frequent mutations of BRAF kinase. MAPK signaling begins when receptor tyrosine kinases bind with their ligand, which transmits activation signals via the RAS GTPase on the cell inner surface (Fig. 1). Once activated, RAS can bind several effector proteins, the best

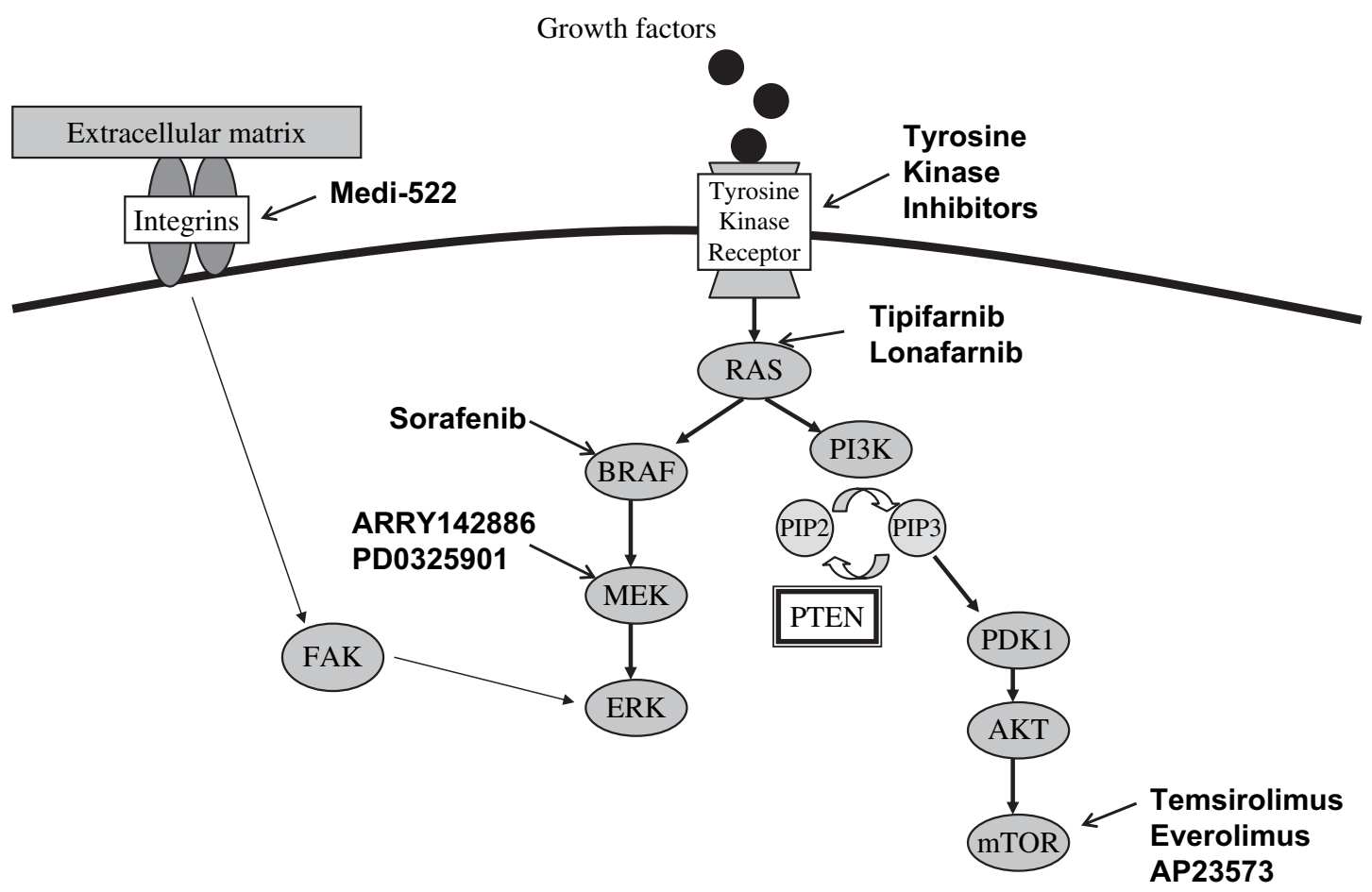

Fig. 1. The MAPK signal transduction pathway. 
characterized of which are RAF and PI3K. The RAF family of kinases (A-RAF, BRAF, and C-RAF) links RAS and the MAPK pathway. Once activated, RAF phosphorylates and activates MAPK/eukaryotic protein kinase (EPK) kinase, which then activates extracellular signal-regulated kinase (ERK). ERK also can be activated when integrins on the cell surface adhere to the extracellular matrix, activating focal adhesion kinase. ERK relays multiple proliferative or survival signals through phosphorylation of a variety of targets in the cytoplasm and nucleus. Aberrant activation of this pathway results in immortalization, growth factor-independent growth, ability to invade and metastasize, and avoidance of apoptosis. Therapeutic targeting of this pathway is approached from many angles. Inhibitors of RAS-MAPK signal transduction include farnesyl transferase inhibitors that interfere with the translocation of RAS to the cell membrane. Direct inhibitors of RAF, such as sorafenib (BAY 43-9006), or of MEK, such as ARRY142886/ AZD6244 and PD0325901, are alternative inhibitory mechanisms.

Sorafenib is a RAF tyrosine kinase inhibitor that inhibits the MAPK pathway. It targets the ATP-binding site of the kinase and, at low concentrations, inhibits wild-type and mutant BRAF and other tyrosine kinase receptors, including vascular endothelial growth factor receptors VEGFR-2 and VEGFR-3, c-kit, and platelet-derived growth factor receptor $\beta$ (PDGFR- $\beta$ ). It is Food and Drug Administration approved in the treatment of advanced renal cell cancer, with the most common toxicities diarrhea, rash, and hand-foot syndrome [10]. As a single agent, sorafenib has not shown significant activity in metastatic melanoma, but in combination with chemotherapy, it is associated with an improvement in response rate and progression-free survival. Based on these responses, an Eastern Cooperative Oncology Group (ECOG) phase III trial was initiated to assess carboplatin and paclitaxel with or without sorafenib. Sorafenib also is being examined in combination with other targeted agents. Other inhibitors that target mutant BRAF specifically also are in clinical trial as are agents that inhibit other targets within the MAPK pathway (Table 2).

Another pathway involved in cell survival is the PI3K pathway, which is altered in a variety of human tumors. After activation through RAS, phosphorylation of PIP2 to PIP3 occurs. This ultimately leads to the activation of Akt (protein kinase B). Phosphatase and tensin homolog deleted on chromosome 10 (PTEN) serves to negatively regulate the PI3K pathway by dephosphorylating PIP3. Akt, once activated, phosphorylates several targets that control cell survival, proliferation, and invasion. At least 13 substrates for Akt are recognized and can be divided into two main subgroups: regulator of apoptosis and regulators of cell growth, protein synthesis, and cell cycle regulation. The PI3K pathway represents another set of targets for therapeutic intervention. A popular target is the mammalian target of rapamycin (mTOR). mTOR is a serine-threonine kinase that functions downstream of Akt. Members of the TOR subfamily are inhibited by rapamycin, a macrolide antibiotic with immunosuppressive properties. 
Table 2

Targeted therapies in clinical trials for melanoma

\begin{tabular}{|c|c|c|c|}
\hline Agent & Company & Targets & Mechanism of action \\
\hline 17-AAG & & HSP90 & Disrupts HSP 90 complexes \\
\hline $\begin{array}{l}\text { Aprinocarsen (Affinitak, } \\
\text { ISIS 3521) }\end{array}$ & ISIS (Carlsbad, CA) & PKC- $\alpha$ & Antisense oligonucleotide \\
\hline ARRY-1422886 & Array BioPharma (Boulder, CO) & MEK & Tyrosine kinase inhibitor \\
\hline AZD2171 & AstraZeneca (Wilmington, DE) & VEGFR, PDGFR, c-KIT, FGFR & Tyroskine kinase inhibitor \\
\hline AZD6244 & AstraZeneca (Wilmington, DE) & MEK & Tyrosine kinase inhibitor \\
\hline Bevacizumab (Avastin) & Genentech (San Francisco, CA) & VEGF & Monoclonal antibody \\
\hline Bortezomib (PS-341, Velcade) & Millenium (Cambridge, MA) & Cell cycle regulatory proteins & Proteasome inhibitor \\
\hline Cilengitide (EMD 121974) & & Integrin & Angiogenesis inhibitor \\
\hline CNTO 95 & Centocor (Horsham, PA) & $\alpha \mathrm{V}$ integrin & Monoclonal antibody \\
\hline Everolimus (RAD001) & Novartis (Basel, Switzerland) & $\mathrm{PI} 3 \mathrm{~K} / \mathrm{AkT} / \mathrm{PTEN}$ & mTOR inhibitor \\
\hline Imatinib (STI-571, Gleevec) & Novartis (Basel, Switzerland) & c-KIT & Tyrosine kinase inhibitor \\
\hline Marimastat (BB2516) & & Matrix metalloproteinases (MMPs) & MMP inhibitor \\
\hline MEDI-522 (Abergrin, Vitaxin) & MedImmune (Gaithersburg, MD) & $\alpha \mathrm{V} \beta 3$ integrin & Monoclonal antibody \\
\hline Oblimersen & & Bcl-2 & Antisense oligonucleotide \\
\hline PD0325901 (CI-1040) & Pfizer (New York, NY) & MEK & Tyrosine kinase inhibitor \\
\hline PI-88 & Progen (Queensland, Australia) & VEGF, FGF 1, FGF 2 & Growth factor inhibitor \\
\hline RAF-265 (Chir 265) & Novartis (Basel, Switzerland) & BRAF, CRAF, VEGFR & Tyrosine kinase inhibitor \\
\hline $\begin{array}{l}\text { Sorafenib (Bay 43-9006, } \\
\text { Nexavar) }\end{array}$ & $\begin{array}{l}\text { Bayer (West Haven, CT) and Onyx } \\
\text { (Richmond, CA) }\end{array}$ & $\begin{array}{l}\text { BRAF, CRAF, PDGFR- } \beta \text {, VEGFR, } \\
\text { FGFR, c-KIT, FLT-3, RET }\end{array}$ & Tyrosine kinase inhibitor \\
\hline Semaxanib (SU5416) & & VEGFR-1 & Tyrosine kinase inhibitor \\
\hline Sunitinib (SU011248, Sutent) & Pfizer (New York, NY) & $\begin{array}{l}\text { VEGFR, PDGFR, FLT-3, c-KIT, } \\
\text { FGFR 1, RET }\end{array}$ & Tyrosine kinase inhibitor \\
\hline Temsirolimus (CCI-779) & Wyeth-Ayerst (Madison, NJ) & PI3K/AkT/PTEN & mTOR inhibitor \\
\hline $\begin{array}{l}\text { Tibifarnib (R115777, } \\
\text { Zarnestra) }\end{array}$ & $\begin{array}{l}\text { Johnson \& Johnson (New } \\
\text { Brunswick, NJ) }\end{array}$ & RAS & Farnesyltransferase inhibitor \\
\hline $\mathrm{UCN}-01$ & & PDK-1, Chk1 kinase & PKC- $\alpha / \beta / \gamma$ inhibitor \\
\hline
\end{tabular}

Abbreviations: FGF, fibroblast growth factor; FGFR, fibroblast growth factor receptor; HSP, heat shock protein; PDGFR, platelet derived growth factor receptor; PKC, protein kinase C; VEGF, vascular endothelial growth factor; VEGFR, vascular endothelial growth factor receptor. 
Temsirolimus (CCI-799) is an ester derivative of rapamycin, which inhibits mTOR kinase activity, which is responsible for the translation of proteins required for progression through the cell cycle. Preclinical investigation of CCI-779 demonstrates growth inhibition in multiple solid tumor lines and animal models. In phase I clinical trials, dose-limiting toxicities included myelosuppression, diarrhea, stomatitis, fatigue, dermatitis, and hyperlipidemia [11]. As a single agent, temsirolimus did not have enough activity to warrant further testing as a single agent [12]. Several ongoing studies are examining its potential when combined with sorafenib, bevacizumab, or other targeted agents. Several other mTOR inhibitors, such as everolimus (Novartis) and AP-23573 (Ariad Pharmaceuticals, Cambridge, Massachusetts), are in phase I and II trials currently open to accrual.

\section{Antiapoptotic therapies}

One of the consequences of constitutive MAPK and PI3K/AkT signal transduction is the deregulation of apoptosis and tissue homeostasis. Drug resistance in melanoma also is attributed partially to overexpression of $\mathrm{Bcl}-2$, an antiapoptotic protein that locks the release of cytochrome $\mathrm{C}$ [13]. Cells transfected with Bcl-2 demonstrate multidrug-resistant phenotype multiple tumor lines. Reciprocal targeted inactivation of Bcl-2 augments chemotherapeutic responses in in vivo models [14].

Oblimersen sodium is an 18-base phosphorothioate antisense oligonucleotide that binds the first six codons of the Bcl-2 mRNA open reading frame and mediates RNA cleavage by $\mathrm{RNase} \mathrm{H}$, thus degrading the message. In xenotransplantation models for human melanoma, down-regulation of Bcl-2 concentration has been observed with the administration of oblimersen and dacarbazine (DTIC) [15]. A phase I/II clinical trial was performed in patients who had metastatic melanoma. Toxicities included fever, liver function abnormalities, rash, and lymphopenia. One complete response and two partial responses were observed [16]. A phase III trial in 771 patients was performed in which randomized patients received DTIC alone or DTIC plus oblimersen given by intravenous infusion. Overall survival was not statistically significant between the two groups (9.1 months for combination group versus 7.9 months for DTIC alone), but the overall response rate favored the combination arm $(11.7 \%$ versus $6.8 \%, P=.019)$.

Another target of apoptosis is nuclear factor $\kappa \mathrm{B}(\mathrm{NF}-\kappa \mathrm{B})$. Its constitutive activation is associated with impaired apoptosis in a variety of tumor lines. In healthy individuals, NF- $\kappa \mathrm{B}$ regulates the expression of genes involved in normal immunologic responses. Persistent activation of NF- $\kappa B$, however, inhibits apoptosis and promotes proliferation leading to hyperplasia. Boronic acid--erived compounds inhibit the proteosome pathway, which helps to control NF- $\kappa \mathrm{B}$ degradation. In the animal models, a combination of a proteosome inhibitor, bortezomib, and temozolimide significantly reduced tumor growth [17]. A phase II study of bortezomib in 27 patients was 
terminated because of lack of clinical responses [18]. Six patients achieved stable disease although four of the six patients were removed from the study for significant toxicities. Median time to disease progression was 1.5 months; however, median overall survival was 14.5 months. Although bortezomib was not effective as a single agent, a phase II trial of combination carboplatin and paclitaxel with bortezomib is ongoing, based on the previous animal models.

\section{Antiangiogenic therapy}

Neoangiogenesis is crucial for continued neoplastic proliferation and metastasis. The development of new vessels is a key step for neoplastic progression. Several proangiogenic factors, including vascular endothelial growth factor (VEGF), basic fibroblastic growth factor (FGF), and transforming growth factor-beta, are produced by tumor cells. Endothelial cells express a family of tyrosine receptor kinases that bind VEGF with high affinity and stimulate several signaling pathways that induce endothelial cell mitosis, migration, and neoangiogenesis [19]. These growth factors serve as potential targets for molecular therapies.

Bevacizumab (Avastin) is a recombinant humanized monoclonal antibody to VEGF that has demonstrated efficacy in patients who have colorectal cancer and improves response and survival when combined with chemotherapy [20]. A phase II randomized trial of bevacizumab with or without low-dose interferon in patients who had stage IV melanoma demonstrated two responses (one complete and one partial) and four prolonged stabilizations of disease [21]. There was no observed added benefit of the low-dose interferon. Additional trials in melanoma are examining bevacizumab in combination with chemotherapy, high-dose interferon, or other targeted therapies. Another agent targeting VEGF activity is SU5416, an inhibitor of VEGFR-1 tyrosine kinase. Although only 1 of 31 patients in a phase II trial in pretreated stage IV melanoma patients had a response, MRI showed a significant decrease in tumor perfusion. There may be a role for SU5416 in combination with chemotherapy.

Thalidomide is a synthetic glutamic-acid derivative first manufactured in the 1950 s as a sedative but was associated with phocomelia and withdrawn from the market. Judah Folkman first elucidated the effect of thalidomide on angiogenesis, showing that thalidomide inhibits basic FGF-induced angiogenesis. Despite the subsequent intensive study of thalidomide as an antiangiogenic agent, the precise mechanism of its activity remains unknown [22]. In addition to its antiangiogenic properties, thalidomide has immunomodulating properties. It costimulates $\mathrm{T}$ cells that have been activated partially by the T-cell receptor (TCR) and inhibits monocyte-derived tumor necrosis factor $\alpha[23,24]$. Thalidomide has been studied as a single agent or in combination with temozolimide in patients who have metastatic melanoma. No objective responses were seen in a phase II clinical trial of 
14 patients who had metastatic melanoma [25], but more favorable results were seen in a study of stage IV melanoma patients who had brain metastases using thalidomide in combination with temozolimide. Three of 15 patients who had evaluable disease demonstrated complete or partial responses. Minor responses or stable disease was observed in seven additional patients [26]. Unfortunately, and despite initial encouraging results, the therapy was associated with significant adverse events, most notably a high rate of thromboembolic events [27].

Not long after the recognition of the antiangiogenic properties of thalidomide, efforts were made to synthesize thalidomide analogs that had fewer side effects than the parent compound. Immunomodulatory drugs (IMiDs) are compounds based on the thalidomide structural backbone. Secondand third-generation IMiDs, including CC 5013 (Revlimid) and CC 4047 (Actimid), exert similar antiangiogenic activity with varying levels of immunomodulating activity. A large phase III trial of CC 5013 versus placebo as second-line therapy in patients who had advanced melanoma was terminated secondary to inactivity of the study drug.

Other targets of antiangiogenic therapies are integrins. The integrin $\alpha \mathrm{V} \beta 3$ can act as the vitronectin receptor, and it seems to play a critical role in melanoma growth and further metastasis. This integrin is specific for tumorassociated vasculature and is required for melanoma cell survival. Integrin $\alpha \mathrm{V} \beta 3$ is up-regulated by VEGF and $\beta$-FGF. It is expressed on a large percentage of cancers, including melanoma, but not by normal melanocytes. Its expression in melanoma primary lesions increases as they progress from the horizontal to vertical growth phases, and tumors from stage IV melanoma patients seem to express the integrin more intensely [28]. MEDI-522 is a humanized form a murine monoclonal antibody to integrin $\alpha \mathrm{V} \beta 3$. A phase II study comparing MEDI-522 (8 $\mathrm{mg} / \mathrm{kg}$ per week) with or without DTIC $\left(1000 \mathrm{mg} / \mathrm{m}^{2}\right.$ once every 3 weeks $)$ in patients who had metastatic melanoma demonstrated no objective responses in the single therapy arm. The combination with DTIC demonstrated a $13 \%$ response rate compared with no responses for the single agent [29]. Without a DTIC alone arm, it is impossible to draw any conclusions, and there were two deaths possibly attributed to MEDI-522, which raises safety concerns.

\section{Immunotherapy of melanoma}

For several decades, vaccines have represented the holy grail of melanoma therapy, a quest driven by frustration with standard chemotherapy and clear evidence of the immune system's ability to recognize and eradicate melanoma. Immunotherapy represents the ideal therapeutic, a natural response that can be initiated in an outpatient setting, has minimal side effects, and has long-lasting memory. Conceptually, there are three criteria necessary for the effective generation of an antitumor response, and they seem within our grasp: the generation of sufficient number of cells with highly 
avid recognition of tumor antigens, appropriate homing of these cells to the tumor targets, and appropriate activation of these cells. Thus, a plethora of vaccines has been developed to optimize the generation of tumor avid lymphocytes, delivered with various types of adjuvants to increase the immunogenicity.

Despite multiple phase I and II trials showing promise (Table 3), phase III trials have been disappointing (Table 4). There are, unfortunately, many hurdles to successful translation of vaccine therapies from preclinical studies to clinical use. One difficulty is the need to balance immunogenicity with feasibility. Approaches that use peptides or allogeneic cells are advantageous in that the treatment easily is standardized and distributed, but these preparations seem to be less immunogenic. Using autologous tumor allows for a broader array of relevant antigens and can generate more powerful immune responses, but the approach is limited to patients who have harvestable tumor. Another problem is finding appropriate surrogates for phase I and II trials. There are limitations to the ability to measure and compare immune responses generated by vaccines accurately, and current surrogate endpoints, such as immunologic assays, tumor infiltration by effector cells, or even partial clinical responses, do not necessarily predict which approaches most likely will result in improved survival. It becomes difficult, therefore, to know which phase I and II data are most worthy of proceeding to prospective, randomized trials. Over the years, several vaccine strategies have been examined with variable results.

\section{Peptide vaccines}

Growing melanoma-specific T-cell clones in vitro has allowed investigators to identify the major histocompatibility complex (MHC)-restricted peptide antigens they recognize [30]. Immunogenic peptides can arise from the genetic mutations that originally led to malignant transformation; they can be from proteins originally expressed on germ cells (which lack MHC molecules so the antigens are silent) but now are expressed openly on cancer cells; or they may be from proteins shared by cancer cells and normal cells. A major benefit of using peptide vaccines is the ability to standardize, mass produce, and test them effectively. As the immunogenicity of peptide antigens alone is weak, the peptides often are delivered to patients along with an immune adjuvant meant to induce inflammation and improve the immunogenicity, pushing the immune process toward immunity rather than tolerance. BCG and DETOX (detoxified Freund's adjuvant, composed of monophosphoryl lipid A and a purified mycobacterial cell-wall skeleton) are examples of adjuvants meant to cause a nonspecific inflammatory response that increases the likelihood of recognition of the administered peptide.

Unfortunately, peptide vaccines have several drawbacks when translated to clinical use. Even if the peptides are recognized, melanoma cells easily can escape recognition through antigenic modulation. Because a $\mathrm{T}$ cell's 
Table 3

Clinical trials of vaccines in melanoma

\begin{tabular}{|c|c|}
\hline Author & Vaccine (adjuvant) \\
\hline \multicolumn{2}{|l|}{ Single peptide vaccines } \\
\hline Rosenberg [121] & gp100 (IFA, IL-2) \\
\hline Cormier [122] & MART-1 (IFA) \\
\hline Rosenberg [123] & gp100 (IFA, IL-12 or GM-CSF) \\
\hline Powell [124] & gp100 (IFA) \\
\hline Speiser [125] & MART-1 (IFA, CpG 7909) \\
\hline Wang [126] & MART-1 (IFA) \\
\hline Marchand [127] & MAGE-3 \\
\hline Scheibenbogen [128] & Tyrosinase (GM-CSF) \\
\hline Jager [129] & NY-ESO-1 (GM-CSF) \\
\hline Khong [130] & NY-ESO-1 (IFA) \\
\hline Phan [131] & gp100 (anti-CTLA4 mAb) \\
\hline \multicolumn{2}{|l|}{ Ganglioside vaccines } \\
\hline Guthmann [132] & $\begin{array}{l}\text { GM3 (Neisseria meningitides outer membrane protein complex, } \\
\text { Montanide ISA 51) }\end{array}$ \\
\hline Livingston [133] & GM2 (BCG) \\
\hline Chapman [134] & GM2 (KLH/QS-21) \\
\hline \multicolumn{2}{|c|}{ Multipeptide or protein vaccines } \\
\hline Chianese-Bullock [34] & $\begin{array}{l}\text { 12, including MAGE-A1, MAGE-A10, gp100 (GM-CSF and } \\
\text { Montanide ISA-51) }\end{array}$ \\
\hline Pullarkat [35] & MART-1, gp100, tyrosinase (IFA, SD-9427 [progenipoietin]) \\
\hline Weber [36] & gp100, tyrosinase (IFA, GM-CSF) \\
\hline Lee [37] & gp100, tyrosinase (IFA, IL-12) \\
\hline Slingluff [38] & gp-100, tyrosinase (THP, IL-2) \\
\hline Atzpodien [39] & MART-1, gp100, tyrosinase (GM-CSF) \\
\hline Sanderson [40] & gp100, MART-1, tyrosinase (Montanide ISA 51, anti-CTLA-4 mAb) \\
\hline Marchand [41] & MAGE-3 protein (MPL + QS21) \\
\hline Davis [42] & NY-ESO-1 protein (ISCOMATRIX) \\
\hline \multicolumn{2}{|l|}{ Allogeneic tumor cells } \\
\hline Belli [135] & IL-12 gene-modified allogeneic cells \\
\hline Maio [136] & IL-4 or IL-2 gene-modified allogeneic cells \\
\hline Das Gupta [137] & IL-2 gene-modified allogeneic cells \\
\hline Morton $[138,139]$ & Canvaxin (BCG) \\
\hline Morton [77] & Canvaxin (BCG) \\
\hline Chan $[84]$ & Canvaxin (BCG) \\
\hline Cassel $[140]$ & Viral Oncolysate using Newcastle Disease Virus \\
\hline Wallack [141] & VMO \\
\hline Hersey [142] & VMCL \\
\hline \multicolumn{2}{|l|}{ Autologous tumor cells } \\
\hline Mahvi [143] & GM-CSF gene-modified autologous tumor cells \\
\hline Kosomoto [144] & GM-CSF gene-modified autologous cells \\
\hline Stingl $[145]$ & IL-2 gene-modified autologous tumor cells \\
\hline Moiseyenko [146] & Tag7/PGRP-s gene-modified autologous tumor cells \\
\hline Soiffer [147] & GM-CSF gene-modified autologous tumor cells \\
\hline Schreiber $[148]$ & IL-2 gene-modified autologous tumor cells \\
\hline Moller [149] & IL-7 gene-modified autologous tumor cells \\
\hline Sun $[150]$ & IL-12 gene-modified autologous tumor cells \\
\hline Abdel-Wahab [151] & IFN- $\gamma$ gene-modified autologous tumor cells \\
\hline Veelken [152] & Autologous tumor cells with IL-2 secreting fibroblasts \\
\hline Nawrocki [153] & $\begin{array}{l}\text { Autologous tumor cells with allogeneic melanoma cells secreting IL-6 } \\
\text { and SIL6R }\end{array}$ \\
\hline Berd [74] & M-Vax \\
\hline
\end{tabular}

Abbreviations: BCG, Bacillus Calmette-Guerin; GM-CSF, granulocyte macrophage colony stimulating factor; IFA, incomplete Freund's adjuvant; IFN, interferon; IL, interleukin; KLH, keyhole limpet hemocyanin; VMCL, vaccinia melanoma cell lysates; VMO, vaccinia melanoma oncosylate. 
Table 4

Phase III randomized studies of melanoma vaccines

\begin{tabular}{|c|c|c|c|c|}
\hline Investigator & Study population & Treatment arms & $\mathrm{N}$ & Results \\
\hline Mitchell & Stage III & $\begin{array}{l}\text { High-dose interferon } \\
\text { versus } \\
\text { Melacine }+ \text { low-dose } \\
\quad \text { interferon }\end{array}$ & 604 & No difference in survival [114] \\
\hline Morton & Stage III & $\begin{array}{l}\text { Canvaxin }+ \text { BCG } \\
\text { versus } \\
\text { placebo }+ \text { BCG }\end{array}$ & 1118 & $\begin{array}{l}\text { Discontinued secondary to } \\
\text { no effect at interim analysis }\end{array}$ \\
\hline Morton & Stage IV resected & $\begin{array}{l}\text { Canvaxin }+ \text { BCG } \\
\text { versus } \\
\text { placebo }+ \text { BCG }\end{array}$ & 670 & $\begin{array}{l}\text { No significant difference in } \\
\text { survival [115] }\end{array}$ \\
\hline ECOG 4697 (group A) & $\begin{array}{l}\text { Stage III or stage } \\
\text { IV resected } \\
\text { HLA-A2+ }\end{array}$ & $\begin{array}{l}\text { GM-CSF + peptide vaccine } \\
\text { versus } \\
\text { GM-CSF + placebo } \\
\text { versus } \\
\text { peptide vaccine + placebo } \\
\text { versus } \\
\text { placebo + placebo }\end{array}$ & $\begin{array}{l}800 \text { for group } \\
\mathrm{A} \text { and } \mathrm{B}\end{array}$ & $\begin{array}{l}\text { Closed to accrual } \\
\text { Results pending }\end{array}$ \\
\hline ECOG 4697 (group B) & $\begin{array}{l}\text { Stage III or stage IV } \\
\text { resected } \\
\text { HLA-A2- }\end{array}$ & $\begin{array}{l}\text { GM-CSF } \\
\text { versus } \\
\text { placebo }\end{array}$ & & $\begin{array}{l}\text { Closed to accrual } \\
\text { Results pending }\end{array}$ \\
\hline EORTC 18961 & T3-T4N0M0 & $\begin{array}{l}\text { GM2-KLH/QS-21 } \\
\text { versus } \\
\text { observation }\end{array}$ & 1350 & $\begin{array}{l}\text { Closed to accrual } \\
\text { Results pending }\end{array}$ \\
\hline Oncophage/antigenics & Stage IV & $\begin{array}{l}\text { HSPPC-96 } \\
\text { versus } \\
\text { physician's choice }\end{array}$ & 322 & $\begin{array}{l}\text { No significant survival benefit } \\
\text { in M1a patients [116] }\end{array}$ \\
\hline
\end{tabular}




\begin{tabular}{|c|c|c|c|c|}
\hline MEDAREX & $\begin{array}{l}\text { Stage III or IV } \\
\text { HLA-A*0201+ }\end{array}$ & $\begin{array}{l}\text { MDX-010 (anti-CTLA-4 } \\
\text { mAb) alone } \\
\text { Versus } \\
\text { MDX-1379 (gp100 vaccine) } \\
\quad \text { alone } \\
\text { versus } \\
\text { MDX-010 and MDX-1379 }\end{array}$ & 750 & Accruing patients \\
\hline $\begin{array}{l}\text { Sondak/Southwest Oncology } \\
\text { Group }\end{array}$ & Stage IB, IIA & $\begin{array}{l}\text { Melacine } \\
\text { versus } \\
\text { observation }\end{array}$ & 689 & No difference in survival [81] \\
\hline Kirkwood/ECOG & Stage III & $\begin{array}{l}\text { High-dose interferon } \\
\text { versus } \\
\text { GM2-KLH/QS-21 vaccine }\end{array}$ & 880 & $\begin{array}{l}\text { Improved survival with HDI } \\
\text { [117] }\end{array}$ \\
\hline Wallack & Stage II & $\begin{array}{l}\text { VMO } \\
\text { versus } \\
\text { placebo }\end{array}$ & 250 & No difference in survival [118] \\
\hline Hersey & Stage IIB and III & $\begin{array}{l}\text { VMCL } \\
\text { versus } \\
\text { placebo }\end{array}$ & & No difference in survival [119] \\
\hline Voit & Stage III & NDV-lysate & 17 & No difference in survival [120] \\
\hline
\end{tabular}


recognition of an antigen depends on the presentation of that antigen on a specific MHC molecule, only in patients who have a specific human lymphocyte antigen (HLA) phenotype can a given peptide induce an immune response. For example, MART-1/Melan-A is a well-defined protein antigen expressed by $80 \%$ of melanomas. This peptide binds to HLA-A2, which is expressed by only approximately $45 \%$ of whites. Therefore, only $36 \%$ of patients $(80 \%$ of $45 \%)$ possibly benefit from a vaccine comprised of MART-1/ Melan-A [31]. Today, many vaccine trials are limited to patients who are HLA-A2 positive.

With these limitations in mind, newer approaches to increasing the immunogenicity of peptide vaccines include modifying the peptides by substituting amino acids (heteroclitic peptides) that increase the affinity of peptide binding [32,33], using multiple peptides [34-40], using entire proteins [41,42], or using anti-idiotype antibodies [43-52]. One of the most promising approaches to peptide vaccination seems to be the combination of tumor peptide antigens with heat shock proteins (HSPs). HSPs are highly conserved intracellular chaperone molecules that carry potentially immunogenic peptides. They are produced by cells in response to stress and when complexed with peptides, they readily are taken up by DCs for presentation to naïve T-cells [53-55]. The combination of tumor peptides and autologous HSPs results in cross-presentation with MHC-class I presentation of exogenous peptide by APCs, ultimately eliciting tumor-specific immunity [56-58]. HSP 70, HSP 90, and HSP 96 seem to play an important role in processing of antigen before being taken up by antigen presenting cells [59-61]. HSP-peptide complexes can be generated by fusing individual peptides to HSPs [60] or readily can be purified from individual tumors for use as a therapy $[61,62]$. In the latter case, it is conceivable that these complexes may represent the total set of processed peptides from a population of tumor cells, although using HSP purified from individual tumors has the same limitations as other approaches requiring autologous tumor. Autologous HSP peptide complex-96 (HSPCC-96 [Oncophage]) has been evaluated in several clinical trials that have demonstrated evidence of immune responses and objective responses [63-66], although a phase III trial of patients who had metastatic melanoma treated by Oncophage or physician's choice failed to demonstrate a clear benefit to the vaccine [67]. There is some suggestion of a survival benefit in M1a disease, and a second phase III trial for M1a and M1b disease is planned.

\section{Cellular vaccines}

Accepting the inherent limitations of using a limited number of peptides, tremendous focus has been placed on using melanoma cells as the antigenic source. The use of autologous tumor theoretically ensures that all biologically relevant antigens are presented to the immune system. Autologous cellular vaccines, however, are a veritable poster child for the obstacles facing 
immunotherapists. Although preclinical studies show these vaccines to be the most immunogenic, early attempts to use irradiated autologous tumor cells as vaccines had little success owing to the poor immunogenicity of native tumor cells themselves $[68,69]$. With the addition of adjuvants, the results improved, albeit modestly [70-72]. Markedly improved results were seen when Berd and colleagues [73] conjugated the hapten ditnitrophenyl to proteins on autologous tumor cells to increase the immunogenicity. A total of 77 patients who had clinically evident nodal metastases were given the vaccine (known as $\mathrm{M}-\mathrm{Vax}$ ) with $\mathrm{BCG}$, in the adjuvant setting after lymphadenectomy. The investigators reported more favorable than expected 5-year relapse-free and overall survival rates (45\% and $58 \%$, respectively) $[74,75]$. An initial randomized trial was attempted; however, there were considerable difficulties with specimen transportation and vaccine manufacturing issues, illustrating the difficulties of doing large trials with autologous vaccines. A new randomized trial was initiated for stage III melanoma comparing MVax to high-dose interferon- $\alpha$, using a lower dose of M-Vax, which requires a smaller amount of a patient's tumor tissue to create the vaccine, but also had difficulties.

Beyond the technical complexities inherent in procuring tumor and preparing a vaccine, another inherent problem with autologous cellular vaccines is that they are limited to individuals who had sufficient tumor for preparation of a vaccine. Therefore, clinical trials, and ultimately the clinical use of autologous cellular vaccines, must be restricted to patients who have bulky nodal or resectable distant metastatic disease. Such patients have a poor overall prognosis and likely have significant residual tumor burden, making them less-than-ideal candidates for any immunotherapeutic approach. For this reason, many investigators have sought an alternative strategy. Given that melanoma-associated antigens are common among a large number of patients, it is reasonable to expect that an allogeneic vaccine, prepared from cultured tumor cell lines, could stimulate a relevant antitumor immune response [76,77]. Allogeneic vaccines can be standardized, preserved, and distributed in a manner akin to peptide vaccines. Unfortunately, this approach also has seen difficulty in clinical translation.

Melacine consists of a lysate of two homogenized melanoma cell lines combined with the adjuvant DETOX. Initial phase I and phase II trials demonstrated a clinical response to Melacine [78], but a phase III trial comparing Melacine with combination chemotherapy in patients who had metastatic melanoma demonstrated no statistically significant difference in median survival duration between the two groups [79]. As Melacine was statistically equivalent to chemotherapy with much less toxicity, it was approved in Canada as a treatment for advanced melanoma [80]. A prospective randomized trial evaluating Melacine in the adjuvant setting for patients who had intermediate-thickness, node-negative melanoma also failed to demonstrate a survival benefit to the vaccine [81]. Retrospective analysis, however, demonstrated a relationship between success of the vaccine and HLA alleles. In their 
initial work, Mitchell and colleagues [80] reported a strong association between patient HLA phenotype and evidence of clinical benefit from Melacine, specifically in patients who expressed at least two of the following five alleles: HLA-A2, A28, B44, B45, and C3. In the randomized trial, the 81 patients in the vaccine arm expressing two or more of these alleles had a better disease-free survival than the 70 patients in the observation arm who had two or more of these alleles (4-year disease-free survival rate $87 \%$ versus $64 \%$, $P=.0001)$. The specific alleles contributing the major component of this effect were HLA-A2 and C3. In the vaccine arm, patients positive for HLA-A2 or HLA-C3 had a significantly better 4-year disease-free survival rate than patients in the observation arm or among patients given the vaccine but negative for both alleles. A follow-up phase III clinical trial to examine Melacine in patients expressing HLA antigens HLA-A2 or HLA-C3 (approximately $59 \%$ of the study patients in the original trial) was planned but, unfortunately, further development of the vaccine was abandoned.

Canvaxin is an allogeneic vaccine composed of three viable, irradiated, melanoma cell lines chosen for their high content of immunogenic melanomaand tumor-associated antigens [82,83]. In a phase II study of patients who had metastatic melanoma, the median survival of treated patients was 23 months compared with 7.5 months for historical controls [77]. A more significant survival advantage was seen in patients who underwent resection of clinically detectable disease before vaccination [84]. In a case-control study of 88 patients who had stage IV melanoma and who had complete resection of metastases followed by Canvaxin who were matched to 88 controls having surgery only, the 5-year survival was $40 \%$ for Canvaxin; this was compared with $13 \%$ for the control group [85]. A similar approach was used in a study to evaluate the use of Canvaxin in patients who had American Joint Committee on Cancer stage III melanoma. Canvaxin was given as adjuvant therapy to 283 patients who underwent lymphadenectomy for palpable nodal disease. Compared to historical controls, the 5-year survival rate increased from $39 \%$ to $53 \%$, and the median survival rate increased from 35.1 months to 90 months $[77,83]$. Unfortunately, two subsequent randomized trials failed to demonstrate any benefit of Canvaxin plus BCG compared with placebo plus BCG in patients who had stage III melanoma and in patients who had stage IV melanoma who have undergone surgical resection.

\section{Dendritic cell vaccines}

DCs are a unique system of cells that induce, sustain, and regulate immune responses. DCs express a variety of molecules at various stages of maturation, allowing them to capture antigens, process them, and then present them to naïve T cells. DCs can prime T cells to class I and class II MHCrestricted antigens and are the most potent cells for the initiation of T-cellmediated immunity [86,87]. Most of the vaccine therapies (described previously) depend on DCs to take up tumor-associated antigens and present 
Table 5

Dendritic cell vaccines in clinical trial in melanoma

\begin{tabular}{ll}
\hline Author & Dendritic cell type (antigens) \\
\hline Nestle [154] & Immature DCs (MART-1, gp100, MAGE-3, tyrosinase) \\
Panelli [155] & Immature DCs (MART-1, gp100) \\
Mackensen [156] & Mature DCs (MAGE-1, MAGE 3, MART-1, gp100, tyrosinase) \\
Toungouz [157] & Immature DCs (MAGE-A1, MAGE-A3) \\
Gajewski [158] & Immature DCs (MAGE-3, MART-1) \\
Thurner [159,160] & Mature DCs (MAGE-3) \\
Schuler-Therner [161] & Mature DCs (MAGE-3) \\
Bancherau [162] & Mature DCs (MART-1, gp100, tyrosinase, MAGE-3) \\
Lau [163] & Immature DC (gp100, tyrosinase) \\
Hersey [164] & Immature DCs (MAGE-3.A2, tyrosinase, gp100, MART-1) \\
Lotze [165] & Immature DCs (MART-1, tyrosinase, gp100) \\
de Vries [166] & Mature DCs (gp100, tyrosinase) \\
Butterfield [167,168] & Mature DCs (MART-1) \\
Chakraborty [169] & Immature DCs pulsed with tumor lysate \\
Chang [170] & Immature DCs pulsed with tumor lysate \\
Nestle [154] & Immature DCs pulsed with tumor lysate \\
Griffioen [171] & Immature DCs pulsed with tumor lysate \\
Dillman [89] & Immature DCs pulsed with tumor cells \\
\hline
\end{tabular}

them to $\mathrm{T}$ cells to generate an immune response. DC vaccines attempt to bypass this step by delivering to the patient DCs already expressing tumor antigens. One approach to DC vaccines is to load exogenous peptides onto the empty MHC class I molecules. This approach is limited, however, to known tumor antigens and to patients who have a given HLA type. In addition, responses are limited to cytotoxic T cells. Another approach is to expose immature DCs to unfractionated tumor material. This allows for antigen expression on MHC class I and class II epitopes and the diversification of immune responses. This approach is attractive in that immune responses can be generated without the need for the molecular characterization of tumor specific antigens. One potential drawback is that these methods may induce potentially toxic autoimmune responses to unknown antigens. Early clinical trials have demonstrated the ability of DC-based vaccination to generate objective tumor responses in melanoma-bearing patients (Table 5). Alternative DC vaccine approaches being examined include the use of tumor RNA; transduction of DCs with retroviruses, poxviruses, or adenoviruses encoding specific antigens; or fusing tumor cells and DCs together $[88,89]$.

\section{Anti-cytotoxic T-lymphocyte-associated protein 4 monoclonal antibodies}

One of the most promising areas of translational research in melanoma is direct immune modulation and the blockade of cytotoxic T-lymphocyte-associated antigenn 4 (CTLA-4). Although much of the research on immunotherapy to date has focused on generating tumor-specific effector cells, 
only recently has it begun to focus on tolerance and the inherent controls on the immune system that dampen this response. Regulatory $\mathrm{T}$ cells play an important role in down-regulating responses to antigens through several mechanisms, including the expression of CTLA-4. CTLA-4 is a cell surface molecule that binds to the B7 family of TCRs. It is up-regulated in activated cells and serves as an immunologic'brake." The role of CTLA-4 initially was suggested by the severe autoimmunity and lymphoproliferative disorders seen in knockout mice. Ultimately, it was shown in a series of preclinical studies that the blockade of CTLA-4, primarily through the use of monoclonal antibodies, could augment an antitumor immune response [90]. Based on these findings, different antibodies blocking CTLA-4 have been developed and moved into clinical trials.

MDX-010 is a humanized anti-CTLA-4 monoclonal antibody. A phase II study of 56 patients who had progressive stage IV melanoma, using two different dosing schedules, resulted in an overall objective response rate of $13 \%$ [91]. When combined with interleukin (IL)-2, a phase I/II study showed an overall response rate of $22 \%$. Ticilimumab (CP-675206) is another human anti-CTLA-4 monoclonal antibody undergoing testing [92]. The use of antiCTLA-4 monoclonal antibodies may be limited by grade III/IV autoimmune toxicities, including severe autoimmune colitis. Multiple phase III studies are ongoing to explore the safety and efficacy of CTLA-4 inhibition further in metastatic and adjuvant settings and alone or in combination with vaccines, other immune modulators, or chemotherapy.

\section{Adoptive immunotherapy}

Passive immunotherapy involves delivering to the host components of the immune system that previously were sensitized to host tumor antigens. These may include antibodies $[93,94]$ or nonspecific lymphoid cells activated in vitro by exposure to high concentrations of IL-2, known as lymphokineactivated killer (LAK) cells [95]. Unfortunately, neither of these approaches has had tremendous success in melanoma. A clinical trial of LAK cells plus IL-2 versus IL-2 alone in stage IV melanoma demonstrated no significant difference in response rates between the two treatments [96]. A more fruitful approach has been to use tumor-specific effector cells for adoptive immunotherapy. Tumor-reactive $\mathrm{T}$ cells are more efficient than LAK cells in mediating tumor regression. The $\mathrm{T}$ cells in patients who have cancer, however, often are functionally impaired [97]. In vitro culture of these $T$ cells can restore their effector function. Although this approach is more complex and expensive, it shows tremendous potential in the clinical setting.

Initial approaches to adoptive cellular immunotherapy involved purification of tumor infiltrating lymphocytes (TIL) from metastatic foci, ex vivo expansion in the presence of high-dose IL-2, and infusion of TIL back into the patient. In human studies, approximately $30 \%$ of TIL from patients who have melanoma exhibit specific cytolytic reactivity [98]. When adoptive 
immunotherapy is performed with TIL, objective responses are seen in $10 \%$ to $30 \%$ of patients $[99,100]$. Several mechanisms are being explored to improve the effectiveness of the $\mathrm{T}$ cells and their ability to traffic and survive at the tumor site. These include activating the cells in the presence of monoclonal antibodies (anti-CD3 or anti-CD28) or irradiated tumor cells, developing methods for isolating and selecting the T-cell subsets most responsible for antitumor reactivity, and genetically engineering the $T$ cells $[101,102]$. Another promising approach has been to lymphodeplete patients using cyclophosphamide and fludarabine before adoptive transfer of $T$ cells [103].

One drawback to adoptive cellular immunotherapy is that harvesting TIL from metastatic foci requires that patients have procurable stage IV disease. This limits the clinical settings in which the effect of this approach might be clinically relevant. Dreno and colleagues $[104,105]$ generated $T$ cells from invaded lymph nodes instead of from metastatic lesions for infusion back into patients who had stage III melanoma. There was no difference in either disease-free survival or overall survival in patients receiving adoptive immunotherapy plus IL-2 compared with patients receiving IL-2 only. One explanation might be that compared with TIL, lymph nodes contain only a small percentage of $\mathrm{T}$ cells that are tumor specific. One method to overcominge this drawback is to give patients a vaccine, then excise the vaccine-draining lymph nodes and use these lymphocytes for adoptive cellular immunotherapy [106-109]. In clinical trials by Chang and colleagues [110,111], patients who had melanoma or renal cell carcinoma received intradermal inoculations of autologous tumor vaccines with BCG. Seven to 10 days later, vaccine-draining lymph nodes were removed, expanded, and delivered back to patients; durable tumor responses were seen in some patients [112]. More recent efforts have focused on developing lymphocytes that are completely independent of preexisting antitumor $\mathrm{T}$ cells. Retroviral gene transduction into peripheral blood mononuclear cells may be one method of achieving this. Peripheral blood mononuclear cells from patients were tranduced with the gene for the TCR$\alpha$ and $-\beta$ chains against the MART- 1 melanoma antigen. Seventeen patients received a nonmyeloablative chemotherapy regimen with fludarabine and cyclophosphamide followed by the administration of the transduced $\mathrm{T}$ cells and IL-2. Two patients had complete responses [113]. These encouraging results have spawned investigations into other TCRs, such as p53.

\section{Summary}

Recent advancements in the fields of molecular biology and immunology have provided a window of opportunity to provide true multimodality treatment for melanoma. As stand-alone therapies or in combination with chemotherapy, the addition of targeted molecular therapies or immunotherapies ultimately may serve an important role in disease control. There are many challenges, however, still faced in moving these promising therapies toward clinical use. To date, the road to improved systemic therapy in melanoma 
is paved with a plethora of approaches that seemed promising but ultimately failed to deliver. Better preclinical models that reflect human melanoma carcinogenesis and the immune response/tolerance to melanoma more accurately are needed. Similarly, superior assays of response for phase I and II trials that may predict the likelihood of clinical success more accurately desperately are needed. In order to understand better why promising preclinical data fail to succeed in clinical evaluation, research must shift from the development of new drugs or methods that generate an immune response to the other side of the equation: how melanoma cells develop resistance or avoid immune recognition. The current concept of translational research also must be re-evaluated. The occasional complete or partial response in stage IV disease may not guarantee clinical success nor does a lack of response against measurable metastatic disease mean that a treatment might not eradicate microscopic disease in the adjuvant setting. It is imperative to redesign the methodology by which new therapies are moved from preclinical studies through clinical testing and ultimately into clinical use, not only to avoid wasting valuable resources on therapies unlikely to succeed but also to avoid giving up on other therapies too soon.

\section{References}

[1] Gilchrest BA, Eller MS, Geller AC, et al. The pathogenesis of melanoma induced by ultraviolet radiation. N Engl J Med 1999;340:1341-8.

[2] Meyskens FL, Farmer PJ, Anton-Culver H. Etiologic pathogenesis of melanoma: a unifying hypothesis for the missing attributible risk. Clin Cancer Res 2004;10:2581-3.

[3] Albino AP, Nanus DM, Mentle IR, et al. Analysis of ras oncogenes in malignant melanoma and precursor lesions: correlation of point mutations with differentiation phenotype. Oncogene 1989;4:1363-74.

[4] Pollock PM, Yu F, Qiu L, et al. Evidence for u.v. induction of CDKN2 mutations in melanoma cell lines. Oncogene 1995;11:663-8.

[5] Vink AA, Moodycliffe AM, Shreedhar V, et al. The inhibition of antigen-presenting activity of dendritic cells resulting from UV irradiation of murine skin is restored by in vitro photorepair of cyclobutane pyrimidine dimers. Proc Natl Acad Sci U S A 1997;94: 5255-60.

[6] Lao CD, Demierre M-F, Sondak VK. Targeting events in melanoma carcinogenesis for the prevention of melanoma. Expert Rev Anticancer Ther 2006;6(11):1559-68.

[7] Hawk E, Viner JL. The critical role of risk-benefit assessments in cancer prevention. Cancer Epidemiol Biomarkers Prev 2005;14:297-8.

[8] Noonan FP, Dudek J, Merlino G, et al. Animal models of melanoma: an HGF/SF transgenic mouse model may facilitate experimental access to UV initiating events. Pigment Cell Res 2003;16:16-25.

[9] Schatzkin A, Gail M. The promise and peril of surrogate end points in cancer research. Nat Rev Cancer 2002;2(1):19-27.

[10] Strumberg D, Richly H, Hilger RA, et al. Phase I clinical and pharmacokinetic study of the Novel Raf Kinase and vascular endothelial growth factor receptor inhibitor BAY 43-9006 in patients with advanced refractory solid tumors. J Clin Oncol 2005;23:965-72.

[11] Raymond E, Alexandre J, Depenbrock H, et al. CCI-779, a rapamycin analog with antitumor activity: a phase I study utilizing a weekly schedule [abstract]. Proc Am Soc Clin Oncol 2000;19:728. 
[12] Margolin K, Longmate J, Baratta T, et al. CCI-779 in metastatic melanoma. Cancer 2005; 104:1045-8.

[13] Schmitt CA, Rosenthal CT, Lowe SW. Genetic analysis of chemoresistance in primary murine lymphomas. Nat Med 2000;6:1029-35.

[14] Jansen B, Schlagbauer-Wadl H, Brown BD, et al. bcl-2 antisence therapy chemosensitizes human melanoma in SCID mice. Nat Med 1998;4:232-4.

[15] Jansen B, Wacheck V, Heere-Rees E, et al. Chemosensitization of malignant melanoma BCL2 antisense therapy. Lancet 2000;356:1728-33.

[16] Millward MJ, Bedikian AY, Conry RM, et al. Randomized multination phase III trial of DTIC with or without Bcl-2 antisense (oblimersen sodium) in patients with advanced malignant melanoma [abstract]. Proceedings of the American Society of Clinical Oncology 2004;7505.

[17] Amiri KI, Horton LW, LaFleur JB, et al. Augmenting chemosensitivity of malignant melanoma tumors via proteosome inhibition: implication for bortezomib as a therapeutic agent for malignant melanoma. Cancer Res 2005;63:4912-8.

[18] Markovic SN, Geyer SM, Dawkins F, et al. A phase II study of bortezomib in the treatment of metastatic malignant melanoma. Cancer 2005;103(12):2584-9.

[19] Yancopoulous GD, Davis S, Gale NW, et al. Vascular-specific growth factors and blood vessel formation. Nature 2000;407:242-8.

[20] Hurwitz H, Fehrenbacher L, Novotny W, et al. Bevacizumab plus irinotecan, flourouracil and leucovorin for metastatic colorectal cancer. N Engl J Med 2004;350:2335-42.

[21] Carson WE, Biber JE, Shah N, et al. A phase 2 trial of recombinant humanized monoclonal anti-vascular endothelial growth factor (VEGF) antibody in patients with malignant melanoma [abstract 2873]. Proc Am Soc Clin Oncol 2003;22.

[22] Bartlett JB, Dredge K, Dalgleish AG. The evolution of thalidomide and its IMiD derivatives as anticancer agents. Nature Reviews 2004;4:314-22.

[23] Haslett PA, Corral LG, Albert M, et al. Thalidomide co-stimulates primary human Tlymphocytes, preferentially inducing proliferation, cytokine production and cytotoxic responses in the CD8 + subset. J Exp Med 1998;187:1885-92.

[24] Sampaio EP, Sarno EN, Galilly R, et al. Thalidomide selectively inhibits tumor necrosis factor alpha production by stimulated human monocytes. J Exp Med 1991;173:699-703.

[25] Reirez AB, Richter MF, Fernandes S, et al. Phase II study of thalidomide in patients with metastatic malignant melanoma. Melanoma Res 2004;14:527-31.

[26] Hwu WJ, Lis E, Menell JH, et al. Temozolomide plus thalidomide in patients with brain metastases from melanoma: a phase II study. Cancer 2005;103:2590-7.

[27] Krown SE, Niedzwiecki D, Hwu WJ, et al. Phase II study of temozolomide and thalidomide in patients with metastaticmelanoma in the brain: high rate of thromboembolic events. Cancer 2006; 107:1883-90.

[28] Gutheil JC, Campbell TN, Pierce PR, et al. Targeted antiangiogenic therapy for cancer using Vitaxin: a humanized monocolonal antibody to the intergrin aVb3. Clin Cancer Res 2000;6:3056-61.

[29] Hersey P, Sosman JA, O'Day SJ, et al. A phase II randomized open label study evaluating the empty tumor activity of MED-522, humanized monoclonal antibody directed against the human aVb3 integrin +/- DTIC in patients with metastatic melanoma. J Clin Oncol 2005;23:2707.

[30] Van Der Bruggen P, Traversari C, Chomez P, et al. A gene encoding an antigen recongized by cytolytic T lymphocytes on a human melanoma. Science 1991;254:1643-7.

[31] Maeuer MJ, Storkus WJ, Kirkwood JM, et al. New treatment options for patients with melanoma: review of melanoma-derived T-cell epitope-based peptide vaccines. Melanoma Res 1996;6:11-24.

[32] Parkhurst MR, Salgaller ML, Southwood S, et al. Improved induction of melanomareactive CTL with peptides from the melanoma antigen gp100 modified at HLA-A*0201 binding residues. J Immunol 1996;157(6):2539-48. 
[33] Dyall R, Bowne WB, Weber LW, et al. Heteroclitic immunization induces tumor immunity. J Exp Med 1998;188(9):1553-61.

[34] Chianese-Bullock KA, Pressley J, Garbee C, et al. MAGE-A1, MAGE-A10 and gp100derived peptides are immunogenic when combined with GM-CSF and montanide ISA-51 adjuvant and administered as part of a multipeptide vaccine. J Immunol 2005;174(5): 3080-6.

[35] Pullarkat V, Lee PP, Scotland R, et al. A phase I trial of SD-9427 with a multipeptide vaccine for resected metastatic melanoma. Clin Cancer Res 2003;9(4):1301-12.

[36] Weber J, Sondak VK, Scotland R, et al. Granulocyte-macrophage-colony-stimulating factor added to a multipeptide vaccine for resected stage II melanoma. Cancer 2003; 97(1):186-200.

[37] Lee PP, Wang F, Kuniyoshi J, et al. Effects of Interleukin-12 on the immune response to a multipeptide vaccine for resected metastatic melanoma. J Clin Oncol 2001;19: 3836-47.

[38] Slingluff CL, Petroni GR, Yamshchikov GV, et al. Immunologic and clinical outcomes of vaccination with a multiepitope melanoma peptide vaccine plus low-dose interleukin-2 administered either concurrently or on a delayed schedule. J Clin Oncol 2004;22(22): 4474-85.

[39] Atzpodien J, Fluck M, Reitz M. Individualized synthetic peptide vaccines with GMCSF in locally advanced melanoma patients. Cancer Biother Radiopharm 2004;19(6): 758-63.

[40] Sanderson K, Scotland R, Lee P, et al. Autoimmunity in a phase I trial of a fully human anti-cytotoxic T-lymphocyte antigen-4 monoclonal antibody with multiple melanoma peptides and Montanide ISA 51 for patients with resected stages III and IV melanoma. J Clin Oncol 2005;23(4):741-50.

[41] Marchand M, Punt CJ, Aamdal S, et al. Immunization of metastatic cancer patients with MAGE-3 protein combined with adjuvant SBAS-2: a clinical report. Eur J Cancer 2003; 39:70-7.

[42] Davis ID, Chen W, Jackson H, et al. Recombinant NY-ESO-1 protein with ISCOMATRIX adjuvant induces broad intergrated antibody and CD $4+$ and $C D 8+T$ cell responses in humans. Proc Natl Acad Sci U S A 2004;101:10697-702.

[43] Lindenmann J. Speculations on idiotypes of homobodies. Ann Immunol (Paris) 1973;124: $171-84$.

[44] Jerne NK. Towards a network theory of the immune system. Ann Immunol (Paris) 1974; 125C:373-89.

[45] Chatterjee MB, Baral N, Chatterjee SK, et al. Counterpoint. Cancer vaccines: singleepitope anti-idiotype vaccine versus multiple-epitope antigen vaccine. Cancer Immunol Immunother 2000;49:133-41.

[46] Bhattacharya-Chatterjee M, Kohler G. Anti-idiotype tumor vaccines. Adv Exp Med Biol 1990;251:113-28.

[47] Chatterjee MB, Foon KA, Kohler H. Idiotypic antibody immunotherapy of cancer. Cancer Immunol Immunother 1994;38:75-82.

[48] Mittelman A, Wang X, Matsumoto K, et al. Antiantiidiotypic response and clinical course of the disease in patients with malignant melanoma immunized with mouse antiidiotypic monoclonal antibody MK2-23. Hybridoma 1995;14:175-81.

[49] Saleh MN, Stapleton JD, Khazaeli MB, et al. Generation of a human anti-idiotypic antibody that mimics the GD2 antigen. J Immunol 1993;151:3390-8.

[50] Saleh MN, Lalisan DY Jr, Pride MW, et al. Immunologic response to the dual murine antiId vaccine Melimmune-1 and Melimmune-2 in patients with high-risk melanoma without evidence of systemic disease. J Immunother (1997) 1998;21(5):379-88.

[51] McCaffery M, Yao TJ, Williams L, et al. Immunization of melanoma patients with BEC2 anti-idiotypic monoclonal antibody that mimics GD3 ganglioside: enhanced immunogenicity when combined with adjuvant. Clin Cancer Res 1996;2:679-86. 
[52] Foon KA, Lutzky J, Baral N, et al. Clinical and immune responses in advanced melanoma patients immunized with an anti-idiotype antibody mimicking disialoganglioside GD2. J Clin Oncol 2000;18(2):376-84.

[53] Przepiorka D, Srivastava PK. Heat shock protein-peptide complexes as immunotherapy for human cancer. Mol Med Today 1998;4(11):478-84.

[54] Janetzki S, Blachere NE, Srivastava PK. Generation of tumour specific cytotoxic Tlymphocytes and memory T-cells by immunization with tumor derived heat-shock proteins gp96. J Immunother 1998;21:269-76.

[55] Castellino F, Boucher PE, Eichelberg K, et al. Receptor-mediated uptake of antigen/heat shock protein complexes results in major histocompatibility complex class I antigen presentation via two distinct processing pathways. J Exp Med 2000;191:1957-64.

[56] Arnold D, Faath S, Rammensee H, et al. Cross priming of minor histocompatibility antigen-specific cytotoxic T-cells upon immunization with the heat shock protein gp96. J Exp Med 1995;182(3):885-9.

[57] Heikema A, Agsteribbe E, Wilschut J, et al. Generation of heat shock protein-based vaccines by intracellular loading of gp96 with antigenic peptides. Immunol Lett 1997;57: 69-74.

[58] Tamura Y, Peng P, Liu K, et al. Immunotherapy of tumors with autologous tumor-derived heat shock protein preparations. Science 1997;278:117-20.

[59] Binder RJ, Blachere NE, Srivastava PK. Heat shock protein chaperoned peptides but not free peptides introduced into the cytosol are presented effeciently by MHC I molecules. J Biol Chem 2001;276(20):17163-71.

[60] Ma J-H, Sui Y-F, Ye J, et al. Heat shock protein 70/MAGE-3 fusion protein vaccine can enhance cellular and humoral immune responses to MAGE-3 in vivo. Cancer Immunol Immunother 2005;54:907-14.

[61] Rivoltini L, Castelli C, Carrabba M, et al. Human tumor-derived heat shock protein 96 mediates in vitro activation and in vivo expansion of melanoma- and colon carcinomaspecific T-cells. J Immunol 2003;171(7):3467-74.

[62] Parmiania G. Phase II study of HSPCC-96 in combination with GM-CSF and IFN-a in stage IV malignant melanoma. Proceedings of the American Society of Clinical Oncology 2004;22(14S):7510.

[63] Parmiani G, Rivoltini L, Belli F, et al. Vaccination of metastatic melanoma patients with the autologous heat-shock protein peptide complex-96 (HSPPC-96, Oncophage) which containes melanoma peptides, results in a specific $\mathrm{T}$-cell response and clinical response. J Clin Oncol 2002;20(20):4169-80.

[64] Rivoltini L, Castelli C, Squarcina P, et al. Heat shock protein gp96 presentation of antigenic peptides leads to in vitro sensitization and in vivo expansion of tumor-specific $\mathrm{T}$ cells [abstract]. Proc Am Assoc Cancer Res 2002:719.

[65] Parmiani G, Belli F, Testori A, et al. Vaccination with autologous heat-shock protein peptide complex-96 (HSPPC-96, Oncophage) in metastatic melanoma [abstract]. Proc Am Assoc Cancer Res 2001:799.

[66] Eton O, East M, Ross MI, et al. Autologous tumor-derived heat-shock protein peptide complex-96 in patients with metastatic melanoma [abstract]. Proc Am Assoc Cancer Res 2000:3463.

[67] Antigenics Press Release. Available at: http://www.antigenics.com/news/2005/1010.phtml. Accessed February 5, 2008.

[68] Mastrangelo MJ, Maguire HC Jr, Sato T, et al. Active specific immunization in the treatment of patients with melanoma. Semin Oncol 1996;23:773-81.

[69] Sun Y, Paschen A, Schandorf D. Cell-based vaccination against melanoma- background, preliminary results and perspective. J Mol Med 1999;77(8):593-608.

[70] Berd D, Maguire HC Jr, McCue P, et al. Treatment of metastatic melanoma with an autologous tumor-cell vaccine: clinical and immunologic results in 64 patients. J Clin Oncol 1990;8(11):1858-67. 
[71] McIllmurray MB, Embleton MJ, Reeves WG, et al. Controlled trial of active immunotherapy in the management of stage IIB malignant melanoma. Br Med J 1977;1(6060):540-2.

[72] Aranha GV, McKhann CF, Grage TB, et al. Adjuvant immunotherapy of malignant melanoma. Cancer 1979;43:1297-303.

[73] Berd D, Maguire HC Jr, Mastrangelo MJ. Treatment of human melanoma with a hapten modified autologous vaccine. Ann NY Acad Sci 1993;690:147-52.

[74] Berd D, Maguire HC Jr, Schuchter LM, et al. Autologous hapten-modified melanoma vaccine as postsurgical adjuvant treatment after resection of nodal metastases. $\mathbf{J}$ Clin Oncol 1997;15:2359-70.

[75] Berd D, Kairys J, Dunton C, et al. Autologous, hapten-modified vaccine as a treatment for human cancers. Semin Oncol 1998;25(6):646-53.

[76] Takahashi T, Johnson TD, Nishinaka Y, et al. IgM anti-ganglioside antibodies induced by melanoma cell vaccine correlate with survival of melanoma patients. J Invest Dermatol 1999;112(2):205-9.

[77] Morton DL, Foshag LJ, Hoon DS, et al. Prolongation of survival in metastatic melanoma after specific immunotherapy with a new polyvalent melanoma vaccine. Ann Surg 1992;216:463-82.

[78] Mitchell MS, Harel W, Kan-Mitchell J, et al. Active specific immunotherapy of melanoma with allogeneic cell lysates. Rationale, results and possible mechanisms of action. Ann N Y Acad Sci 1993;690:153-66.

[79] Mitchell MS, Von Eschen KB. Phase III trial of Melacine melanoma vaccine versus combination chemotherapy in the treatment of stage IV melanoma [abstract]. Proceedings of the American Society of Clinical Oncology 1997;16:1778.

[80] Mitchell MS, Harel W, Groshen SG. Association of HLA phenotype with response to active specific immunotherapy of melanoma. J Clin Oncol 1992;10:1158-64.

[81] Sondak VK, Liu PY, Tuthill RJ, et al. Adjuvant immunotherapy of resected, intermediatethickness, node-negative melanoma with an allogeneic tumor vaccine: overall results of a randomized trial of the Southwest Oncology Group. J Clin Oncol 2002;20(8):2058-66.

[82] Morton DL, Barth A. Vaccine therapy for malignant melanoma. CA Cancer J Clin 1996;46: 225-44.

[83] Chan AD, Morton DL. Active immunotherapy with allogeneic tumor cell vaccines: present status. Semin Oncol 1998;25:611-22.

[84] Morton DL. Cytoreductive surgery and adjuvant immunotherapy in the management of metastatic melanoma. Tumori 2001;87(4):S57-9.

[85] Hsueh EC, Nizze A, Essner R, et al. Adjuvant immunotherayp with a polyvalent melanoma cell vaccine (PMCV) prolongs survival after complete resection of distant melanoma metastases [abstract]. Proceedings of the American Society of Clinical Oncology 1997;16:492.

[86] Banchereau J, Steinman RM. Dendritic cells and the control of immunity. Nature 1998;392: 245-52.

[87] Dhodapkar MV, Steinman RM, Sapp M, et al. Rapid generation of broad T-cell immunity in humans after a single injection of mature dendritic cells. J Clin Invest 1999;104: $173-80$.

[88] Trefzer U, Herberth G, Wohlan K, et al. Tumour-dendritic hybrid cell vaccination for the treatment of patients with malignant melanoma: immunological effects and clinical effects. Vaccine 2005;23:2367-73.

[89] Dillman R, Selvan S, Schiltz P, et al. Phase I/II trial of melanoma patient-specific vaccine of proliferating autologous tumor cells, dendritic cells and GM-CSF: planned interim analysis. Cancer Biotherapy \& Radiopharmaceuticals 2004;19(5):658-65.

[90] Sabel MS, Hess SD, Egilmez NK, et al. CTLA-4 blockade augments human T lymphocyte mediated suppression of lung tumor xenografts in SCID mice. Cancer Immunol Immunother 2005;54:944-52.

[91] Attia P, Phan GQ, Maker AV, et al. Autoimmunity correlates with tumor regression in patients with metastatic melanoma treated with anti-CTLA-4. J Clin Oncol 2005;23: 6043-53. 
[92] Ribas A, Camacho LH, Lopez-Berestein G, et al. Antitumor activity in melanoma and antiself responses in a phase I trial with the anti-CTLA-4 monoclonal antibody CP-675206. J Clin Oncol 2005;23:8968-77.

[93] Irie RF, Matsuki T, Morton DL. Human monoclonal antibody to ganglioside GM2 for melanoma treatment. Lancet 1989;1:786-7.

[94] Irie RF, Morton DL. Regression of cutaneous metastatic melanoma by intralesional injection with human monoclonal antibody to ganglioside GD2. Proc Natl Acad Sci U S A 1986; 83:8694-8.

[95] Grimm EA, Robb RJ, Roth JA, et al. Lymphokine-activated killer cell phenomenon, III: evidence that IL-2 is sufficient for direct activation of peripheral blood into lymphokineactivated killer cells. J Exp Med 1983;158:1356-61.

[96] Rosenberg SA, Lotze MT, Topalian SL, et al. Prospective randomized trial of high-dose interleukin-2 alone or in conjuction with lymphokine activated killer cells for the treatment of patients with advanced cancer. J Natl Cancer Inst 1993;85:622-32.

[97] Rivoltini L, Carabba M, Huber V, et al. Immunity to cancer: attack and escape in T lymphocyte-tumor cell interaction. Immunol Rev 2002;188:97-113.

[98] Topalian SL, Solomon D, Rosenberg SA. Tumor specific cytolysis by lymphocytes infiltrating human melanomas. J Immunol 1989;142:3714-25.

[99] Rosenberg SA, Yannelli JR, Yang JC, et al. Treatment of patients wtih metastatic melanoma with autologous tumor-infiltrating lymphocytes and interleukin-2. J Natl Cancer Inst 1994;86:1159-66.

[100] Ridolfi L, Ridolfi R, Riccobon A, et al. Adjuvant immunotherayp with tumor infiltrating lymphocytes and interleukin-2 in patients with resected stage III and IV melanoma. J Immunother 2003;26:156-62.

[101] Li Q, Chang AE. Adoptive T-cell immunotherapy of cancer. Cytokines Cell Mol Ther 1999; 5:105-17.

[102] Speiser DE, Romero P. Toward improved immunocompetence of adoptively transferred CD8 + T cells. J Clin Invest 2005;115(6):1467-9.

[103] Rosenberg SA, Dudley ME. Cancer regression in patietns with metastatic melanoma after the transfer of autologous antitumor lymphocytes. Proc Natl Acad Sci U S A 2004; 101(Suppl 2):14639-45.

[104] Labarriere N, Pandolfino MC, Gervois N, et al. Therapeutic efficacy of melanoma-reactive TIL injected in stage III melanoma patients. Cancer Immunol Immunother 2002;51: $532-8$.

[105] Dreno B, Nguyen JM, Khammari A, et al. Randomized trial of adoptive transfer of melanoma tumor-infiltrating lymphocytes as adjuvant therapy for stage III melanoma. Cancer Immunol Immunother 2002;51:539-46.

[106] Meijer SL, Dois A, Urba WJ, et al. Adoptive cellular therapy with tumor vaccine draining lymph node lymphocytes after vaccination with HLA-B7/beta2-microglobulin gene modified autologous tumor cells. J Immunother 2002;25(4):359-72.

[107] Geiger JD, Wagner P, Shu S, et al. A novel role for autologous tumor cell vaccination in the immunotherapy of the poorly immunogenic B16-BL6 melanoma. Surg Oncol 1992;1: 199-208.

[108] Geiger JD, Wagner P, Cameron M, et al. Generation of T-cells reactive to the poorly immunogenic B16-BL6 melanoma with efficacy in the treatment of spontaneous metastases. J Immunother 1993;13:153-65.

[109] Winter $\mathrm{H}, \mathrm{Hu} \mathrm{H}-\mathrm{M}$, Poehlein $\mathrm{CH}$, et al. Tumour-induced polarization of tumor vaccinedraining lymph node $\mathrm{T}$ cells to a type 1 cytokine profile predicts inherent strong immunogenicity of the tumour and correlates with therapeutic efficacy in adoptive transfer study. Immunology 2003;108:409-19.

[110] Chang AE, Aruga A, Cameron MJ, et al. Adoptive immunotherapy with vaccine-primed lymph node cells secondarily activated with anti-CD3 and interleukin-2. J Clin Oncol 1997;15:796-807. 
[111] Chang AE, Yoshizawa H, Sakai K, et al. Clinical observations on adoptive immunotherapy with vaccine-primed T-lymphocytes secondarily sensitized to tumor in vitro. Cancer Res 1993;53:1043-50.

[112] Chang AE, Li Q, Jiang G, et al. Phase II trial of autologous tumor vaccination, anti-CD3activated vaccine-primed lymphocytes, and interleukin-2, in Stage IV renal cell cancer. J Clin Oncol 2003;21(5):884-90.

[113] Morgan RA, Dudley ME, Wunderlich JR, et al. Cancer regression in patients after transfer of genetically engineered lymphocytes. Science 2006;314:126-9.

[114] Mitchell MS, Abrams J, Thompson JA, et al. Randomized trial of an allogeneic melanoma lysate vaccine with low dose interferon alfa- $2 \mathrm{~b}$ compared with high dose interferon alfa $2 \mathrm{~b}$ for resected stage III cutaneous melanoma. J Clin Oncol 2007;25(15):2078-85.

[115] Morton DL, Mozzillo N, Thompson JF, et al. An international, randomized, double-blind, phase 3 study of the specific active immunotherapy agent, Onamelatucel-L (Canvaxin), compared to placebo as a post-surgical adjuvant in AJCC stage IV melanoma. Ann Surg Oncol 2006;13(Suppl 5):5.

[116] Richards JM, Testori A, Whitman E, et al. Autologous tumor-derived HSPPC-96 vs. physician's choice (PC) in a randomized phase III trial in stage IV melanoma. Proceedings of the American Society of Clinical Oncology 2006;24(Suppl 18):8002.

[117] Kirkwood JM, Ibrahim JG, Sosman JA, et al. High-dose interferon alfa-2b significantly prolongs relapse-free and overall survival compared with the GM2-KLH/QS-21 vaccine in patients with resected stage IIB-III melanoma: results of intergroup trial E1694/S9512/ C509801. J Clin Oncol 2001;19(9):2370-80.

[118] Wallack MK, Sivanandham M, Balch CM, et al. A phase III randomized, double-blind multiinstitutional trial of vaccinia melanoma oncosylate-active specific immunotherapy for patients with stage II melanoma. Cancer 1995;75(1):34-42.

[119] Hersey P, Coates AS, McCarthy WH, et al. Adjuvant immunotherapy of patients with high-risk melanoma using vaccinia viral lysates of melanoma: results of a randomized trial. J Clin Oncol 2002;20(20):4181-90.

[120] Voit C, Kron M, Schwurzer-Voit M, et al. Intradermal injection of Newcastle disease virus-modified autologous melanoma cell lysate and interleukin-2 for adjuvant treatment of melanoma patients with resectable stage III disease. J Dtsch Dermatol Ges 2003;1: $120-5$.

[121] Rosenberg SA, Yang JC, Schwartzentruber DJ, et al. Immunologic and therapeutic evaluation of a synthetic peptide vaccine for the treatment of patients with metastatic melanoma. Nat Med 1998;4:321-7.

[122] Cormier JN, Salgaller ML, Prevette T, et al. Enhancement of cellular immunity in melanoma patients immunized with a peptide from MART-1/Melan-A. Cancer J Sci Am 1997;3:37-44.

[123] Rosenberg SA, Yang JC, Schwartzentruber DJ, et al. Impact of cytokine administration on the generation of antitumor reactivity in patients with metastatic melanoma receiving a peptide vaccine. J Immunol 1999;163:1690-5.

[124] Powell DJ, Rosenberg SA. Phenotypic and functional maturation of tumor antigenreactive $\mathrm{CD} 8+\mathrm{T}$ lymphocytes in patients undergoing multiple course peptide vaccination. J Immunother 2004;27(1):36-47.

[125] Speiser DE, Lienard D, Rufer N, et al. Rapid and strong human CD8 + T cell responses to vaccination with peptide, IFA and CpG oligodeoxynucleotide 7909. J Clin Invest 2005; 115(3):739-46.

[126] Wang F, Bade E, Kuniyoshi J, et al. Phase I trial of a MART-1 peptide vaccine with incomplete Freund's adjuvant for resected high-risk melanoma. Clin Cancer Res 1999;5: 2756-65.

[127] Marchand M, Van Baren N, Weynants P, et al. Tumor regressions observed in patients with metastatic melanoma treated with an antigenic peptide encoded by gene MAGE-3 and presented by HLA-1. Int J Cancer 1999;80:219-30. 
[128] Scheibenbogen C, Schmittel A, Keilholz U, et al. Phase II trial of vaccination with tyrosinase peptides and granulocyte-macrophage colony stimulating factor in patients with metastatic melanoma. J Immunother 2000;23:275-81.

[129] Jager E, Gnjatic S, Nagata Y, et al. Induction of primary NY-ESO-1 immunity; CD8 + T lymphocyte and antibody response in peptide-vaccinated patients with NY-ESO-1 + cancers. Proc Natl Acad Sci U S A 2000;97:12198-203.

[130] Khong HT, Yang JC, Topalian SL, et al. Immunization of HLA-A*0201 and/or HLADPbeta $1 * 04$ patients wtih metastatic melanoma using epitopes from the NY-ESO-1 antigen. J Immunother 2004;27(6):472-7.

[131] Phan GQ, Yang JC, Sherry RM, et al. Cytotoxic regression and autoimmunity induced by cytotoxic $\mathrm{T}$ lymphocyte-associated antigen 4 blockade in patietns wtih metastatic melanoma. Proc Natl Acad Sci U S A 2003;100(14):8372-7.

[132] Guthman MD, Bitton RJ, Carnero AJ, et al. Active specific immunotherapy of melanoma with a GM3 ganglioside-based vaccine: a report on safety and immunogenicity. J Immunother 2004;27(6):442-51.

[133] Livingston PO, Wong GY, Adluri S, et al. Improved survival in stage III melanoma patients with GM2 antibodies: a randomized trial of adjuvant vaccination with GM2 ganglioside. J Clin Oncol 1994;12(5):1036-44.

[134] Chapman BP, Morissey DM, Panageas KS, et al. Induction of antibodies against GM2 ganglioside by immunizing melanoma patients using GM2-KLH + QS21 vaccine: a dose-response study. Clin Cancer Res 2000;6:874-9.

[135] Belli F, Arienti F, Sule-Soso J, et al. Active immunization of metastatic melanoma patients with interleukin-2 transduced allogeneic melanoma cells: evaluation of efficacy and tolerability. Cancer Immunol Immunother 1997;44:197-203.

[136] Maio M, Fonsatti E, Lamaj E, et al. Vaccination of stage IV patients with allogeneic IL-4or IL-2-gene transduced melanoma cells generates functional antibodies against vaccinating and autologous melanoma cells. Cancer Immunol Immunother 2002;51(1):9-14.

[137] Das Gupta TK, Cohen EP, Richards JM. Phase I evaluation of interleukin-2 transfected irradiated allogeneic melanoma for the treatment of metastatic melanoma. Hum Gene Ther 1997;8(14):1701-14.

[138] Hsueh EC, Gupta RK, Qi K, et al. Correlation of specific immune responses with survival in melanoma patients with distant metastases receiving polyvalent melanoma cell vaccine. J Clin Oncol 1998;16:2913-20.

[139] Morton DL, Hsueh EC, Essner R, et al. Prolonged survival of patients receiving active immunotherapy with Canvaxin therapeutic polyvalent vaccine after complete resecton of melanoma metastatic to regional lymph nodes. Ann Surg 2002;236(4):438-49.

[140] Cassel WA, Murray DR, Phillips HS. A phase II study on the postsurgical management of stage II malignant melanoma with a Newcastle disease virus oncosylate. Cancer 1983;52: $856-60$.

[141] Wallack MK, McNally KR, Leftheriotis E, et al. A Southeastern Cancer Study Group phase I/II trial with vaccinia melanoma oncosylates. Cancer 1986;57(3):649-55.

[142] Hersey P. Active immunotherapy with viral lysates of micrometastases following surgical removal of high risk melanoma. World J Surg 1992;16:251-60.

[143] Mahvi DM, Shi FS, Yang NS, et al. Immunization by particle-mediated transfer of the granulocyte-macrophage colony-stimulating factor gene into autologous tumor cells in melanoma or sarcoma patients: report of a phase I/IB study. Hum Gene Ther 2002; 13(14):1711-21.

[144] Kosomoto M, Umeda S, Ikubo A, et al. Phase 1 clinical trial of irradiated autologous melanoma cells adenovirally transduced with human GM-CSF gene. Cancer Immunol Immunother 2001;50(7):373-81.

[145] Stingl G, Brocker EB, Mertelsmann R, et al. Phase I study to the immunotherapy of metastatic malignant melanoma by a cancer vaccine consisting of autologous cancer cells transfected with the human IL-2 gene. J Mol Med 1997;75(4):297-9. 
[146] Moiseyenko VM, Danilov AO, Baldueva IA, et al. Phase I/II trial of gene therapy with autologous tumor cells modified with tag7/PGRP-S gene in patients with disseminated solid tumors. Ann Oncol 2005;16(1):162-8.

[147] Soiffer R, Lynch T, Mihm MF, et al. Vaccination with irradiated autologous melanoma cells engineered to secrete human granulocyte-macrophage colony stimulating factor generates potent anti-tumor immunity in patients with metastatic melanoma. Proc Natl Acad Sci U S A 1998;85:13141-6.

[148] Schreiber S, Kampgen E, Wagner E, et al. Immunothearpy of metastatic melanoma by a vaccine consisting of autologous interleukin 2-transfected cancer cells: outcome of a phase I study. Hum Gene Ther 1999;10(6):983-93.

[149] Moller P, Sun Y, Dorbic T, et al. Vaccination with IL-7 gene-modified autologous melanoma cells can enhance the anti-melanoma lytic activity in peripheral blood of patients with a good clinical performance status: a clinical phase I study. Br J Cancer 1998;77: 1907-16.

[150] Sun Y, Jurgovsky K, Moller P, et al. Vaccination with IL-12 gene modified autologous melanoma cells: preclinical results and a first clinical phase I study. Gene Ther 1998;5: 481-90.

[151] Abdel-Wahab Z, Weltz C, Hester D, et al. A phase I clinical trial of immunotherapy with interferon-gamma gene modified autologous melanoma cells: monitoring the humoral immune response. Cancer 1997;80:401-12.

[152] Veelken H, Mackensen A, Lahn M, et al. A phase I clinical study of autologous tumor cells plus interleukin-2 gene transfected allgeneic fibroblasts as a vaccine in patients with cancer. Int J Cancer 1997;6:269-77.

[153] Nawrocki S, Murawa P, Malicki J, et al. Genetically modified tumour vaccines (GMTV) in melanoma clinical trials. Immunol Lett 2000;74:81-6.

[154] Nestle FO, Alijagic S, Gilliet M, et al. Vaccination of melanoma patients with peptide- or tumor lysate-pulsed dendritic cells. Nat Med 1998;4(3):328-32.

[155] Panelli MC, Wunderlich J, Jeffries J, et al. Phase 1 study in patients with metastatic melanoma of immunization with dendritic cells presenting epitopes derived from the melanomaassociated antigens MART-1 and gp100. J Immunother 2000;23:487-98.

[156] Mackensen A, Herbst B, Chen JL, et al. Phase I study in melanoma patients of a vaccine with peptide-pulsed dendritic cells generated in vitro from CD34 (+) hematopoietic progenitor cells. Int J Cancer 2000;86(3):385-92.

[157] Toungouz M, Libin M, Bulte F, et al. Transient expansion of peptide-specific lymphocytes producing IFN-gamma after vaccination with dendritic cells pulsed with MAGE peptides in patients with MAGE-A1/A3 positive tumors. J Leukoc Biol 2001;69:937-43.

[158] Gajewski GF, Fallarino F, Ashikari A, et al. Immunization of HLA-A2 + melanoma patients wtih MAGE-3 or MelanA peptide-pulsed autologous peripheral blood mononuclear cells plus recombinant human interleukin-12. Clin Cancer Res 2001;7:895s-901s.

[159] Thurner B, Haendle I, Roder C, et al. Vaccination with Mage-3A1 peptide-pulsed mature, monocyte-derived dendritic cells expands specific cytotoxic $\mathrm{T}$ cells and induces regression of some metastases in advanced stage IV melanoma. J Exp Med 1999;190(11): 1669-78.

[160] Godelaine D, Carrasco J, Lucas S, et al. Polyclonal CTL responses observed in melanoma patients vaccinated with dendritic cells pulsed with a MAGE-3.A1 peptide. J Immunol 2003;171(9):4893-7.

[161] Schuler-Thurner B, Dieckmann D, Keikavoussi P, et al. Mage-3 and influenza-matrix peptide-specific cytotoxic T cells are inducible in terminal stage HLA-A2.1 + melanoma patietns by mature monocyte derived dendritic cells. J Immunol 2000;165:3492-6.

[162] Banchereau J, Palucka AK, Dhodapkar MV, et al. Immune and clinical responses in patients with metastatic melanoma to CD34 + progenitor-derived dendritic cell vaccine. Cancer Res 2001;61:6451-8. 
[163] Lau R, Wang F, Jeffery GG, et al. Phase I trial of intravenous peptide-pulsed dendritic cells in patients with metastatic melanoma. J Immunother 2001;24:66-78.

[164] Hersey P, Menzies SW, Halliday GM, et al. Phase I/II study of treatment with dendritic cell vaccines in patients with disseminated melanoma. Cancer Immunol Immunother 2004; 53(2):125-34.

[165] Lotze MT, Shurin M, Esche C, et al. Interleukin-2 developing additional cytokine gene therapy using fibroblasts or dendritic cells to enhance tumor immunity. Cancer J Sci Am 2000;6:S61-6.

[166] de Vries IJ, Bernsen MR, Lesterhuis WJ, et al. Immunomonitoring tumor-specfic T-cells in delayed-type hypersensitivity skin biopsies after dendritic cell vaccination correlates with clinical outcome. J Clin Oncol 2005;23(24):5779-87.

[167] Butterfield LH, Ribas A, Dissette VB, et al. Determinant spreading associated with clinical response in dendritic cell-based immunohterapy for malignant melanoma. Clin Cancer Res 2003;9:998-1008.

[168] Ribas A, Glaspy JA, Lee Y, et al. Role of dendritic cell phoenotype, determinant spreading, and negative costimulatory blockade in dendritic cell-based melanoma immunotherapy. J Immunother 2004;27(5):354-67.

[169] Chakraborty NG, Sporn JR, Tortora AF, et al. Immunization with a tumor-cell-lysate loaded autologous-antigen presenting cell based vaccine in melanoma. Cancer Immunol Immunother 1998;47:58-64.

[170] Chang AE, Redman BG, Whitfield JR, et al. A phase I trial of tumor lysate pulsed dendritic cells in the treatment of advanced cancer. Clin Cancer Res 2002;8:1021-32.

[171] Griffioen M, Borghi M, Schrier PI, et al. Analysis of T-cell responses in metastatic mealnoma patients vaccinated with dendritic cells pulsed with tumor lysates. Cancer Immunol Immunother 2004;3:715-22. 